\title{
The Effect of Ethical Ideology on Earnings Management Practices
}

\author{
Herman Yosef Sri Widodo ${ }^{1}$ \\ ${ }^{1}$ Universitas Atma Jaya Yogyakarta \\ sri widodo6355@yahoo.co.id
}

\begin{abstract}
Earnings management is taking advantage of the flexibility in the choice of accounting treatment to signal the manager's private information on future cash flows (Sankar and Subramanyam, 2001). Earnings management can be defined as the practice of using tricks to misrepresent or reduce transparency of the financial reports (Miller and Bahnson, 2002). Ethical ideology consists of the degree of relativism (use of universal moral rules) and idealism (belief that good can come of all situations) exhibited by individuals when they make an ethical decision (Forsyt, 1981). The aim of this research is to examine the influence of ethical ideology on earnings management practices. This study tested hypotheses that Ethical Ideology can influence negatively to the intention of earnings management. For this purpose, the data are collected from 121 students who have already passed Auditing and Business Ethics courses in Accounting Study Program, The Faculty of Business and Economics, Universitas Atma Jaya Yogyakarta. The data was analysed by using SPSS16 version. The result of this research shows that ethical ideology has negative effect on the intention of earnings management

Keywords: earnings management, ethical ideology
\end{abstract}

JEL : : G39

DOI : : 10.24002/kinerja.v22i2.3228

Received : 01/29/2020 Reviewed: 01/31/2020 Final Version: 02/20/2020

\section{INTRODUCTION}

\subsection{Research Background}

Earnings management can be defined as any action taken by the management that affects net income and which provides real economic benefits (no true economic advantage) to the organization and can even harm the company in the long run (Merchant \& Rockness, 1994: 79). Accounting information is very important as a basis for decision making, including investment decisions.

Before investing, investors will first conduct an analysis of the company's performance which will be considered in the formation of its portfolio. If the 
information that will be used as a basis for decision making contains an element of truth because it has been prepared by carrying out earnings management, then investment decisions that will be made by investors carry the risk of error as well. Errors in decision making will have an adverse risk for investors in the future.

In the business world, ethical principles are applied in conducting business, known as the field of Business Ethics studies. This field of study has emerged in the United States and Europe since the $80 \mathrm{~s}$, triggered by three main reasons, namely (De George, 1995):

1. There have been many scandals committed by businesspeople which ultimately harm the wider community. For example: The Bophal tragedy in India caused by Union Carbide which killed thousands and injured tens of thousands. The Exxon Valdes case that pollutes the sea between Alaska and California, the Ford Pinto case that causes car users to always die in an accident. This condition was triggered by the adoption of The Myth of Amoral Business by businesspeople. The Amoral Business Myth is a belief held by businesspeople who separates business from ethics, or in other words in doing business it does not have to consider ethical values and believe that the meaning of business is profit maximization. With the slogan the meaning of business is profit, the profit is used as the ultimate goal. In such conditions, businesspeople will try to achieve these goals without considering ethical values or rules.

2. Economization is always the spearhead in improving people's welfare. With this belief the development of the economic sector takes priority over the development of other sectors. As a result, the development of a rapidly advancing economic sector is not matched by development in the legal, educational and cultural sectors so that legal and cultural awareness is lagging.

3. There are more severe business challenges in the future. Rapid environmental changes have caused the business world to face challenges in the future because people are starting to realize and will claim their rights. Business in the future must be run fairly, honestly and respect the rights of all business stakeholders. The company's failure to overcome these challenges will result in the abandonment of the company by its customers.

In the last decade there have been a lot of researches related to earnings management. Various findings from various points of view have been submitted by many researchers. Brunsdan Merchant (1990) was the first researcher to conduct research on perceptions of respondents' acceptance of earnings management practices. This study asks respondents to rate 13 items of earnings management practice. The results of this study are surprising, in general this practice is not something that is explicitly prohibited. This is a minor accounting deviation which 
can thus be categorized as ethical practice regardless of the interests of the users of information (Bruns \& Merchant, 1990).

After the emergence of the Enron and World Com case, questions relating to values and ethics in the field of accounting have become a broad discussion and an interesting topic to study. The company's failure is not solely a matter of accounting and auditing but rather involves a variety of factors including personal values, integrity and ethics (Akers, Eaton \& Giacomino 2004). Thus, various studies relating to the topic began to be carried out such as: Merchant \& Rockness, 1994; Rosenzweig \& Fischer, 1994; Fischer \& Rosenzweig, 1995; Clikeman, Geiger \& O'Connell, 2001; Kaplan, 2001; Elias, 2002; Giacomino et al., 2006).

Accounting Study Program, Faculty of Economics Universitas Atma Jaya Yogyakarta has included Business Ethics courses starting in the year. Thus, the students have instilled ethical and moral values in conducting business both in terms of business institutions, business policies and business decision making. The students have also been provided with material on Professional Ethics in the Auditing course. Armed with the knowledge they have; students should be able to analyze various business practices in terms of ethics including the earnings management practice.

The purpose of this study is to examine the effect of Ethical Ideology on shortterm earnings management practices. The respondents of this study were students of the Accounting Study Program at the Faculty of Business and Economics, Universitas Atma Jaya Yogyakarta, who had passed Auditing and Business Ethics courses.

\section{LITERATURE REVIEW}

\subsection{Ethical Ideology in Running a Business}

Researches in the field of Business Ethics has also been widely carried out such as: De Connick \& Lewis (1997) on the influence of deontological and teleological aspects and ethical climate on the intentions of sales force behavior, Ashman et al., (2006) on ethical organizational commitment, Henle \& Jurkiewicz ( 2005) about the role of ethical ideology in deviations in the workplace and Widodo (2012) about the role of ethical ideology as a moderating variable between organizational commitment and budgetary slack.

Discussing about dysfunctional behavior in budgeting is closely related with applied ethics better known as business ethics:

Ethics is the discipline one's moral standards or the moral standards of society. It asks how these standards apply to our lives and whether these standards are reasonable or unreasonable.... Business Ethics is a specialized study of moral right and wrong. It concretes on moral standards as they apply to business institutions, organizations and behavior (Velasques, 2006: 10-12). 
Of the two definitions outlined previously, businesspeople can be assessed for their behavior by using standards called moral norms. Thus, it can be concluded that the manager is said to be ethical if he applies his moral norms when he faces a dilemma in making decisions when running his business. From this understanding it can also be concluded that the practice of business ethics can be carried out at the individual level, at the organizational level and at the community level.

Ethical Decision Making in business requires the individuals involved to evaluate various alternatives. The moral foundation of a manager has a significant influence on the awareness of alternatives (DeConinck \& Lewis, 1997). There are two major streams in philosophy about ethics namely Teleology and Deontology (Schlenker \& Forsyth 1977). The Teleological School evaluates whether an ethical action is based on the consequences of that action, and actions are considered ethical if they produce as many benefits as possible for as many people. While the Deontology school evaluates the ethics of an action based on certain norms and does not consider the consequences of that action. Ethical ideology is used by someone to make moral judgments in order to judge whether the decision taken will be questioned ethically. Thus, Ethical Ideology will guide someone to do something right or wrong, good or bad, just or unjust. Ethical ideology influences various decision making in business practices (Forsyth 1992). Ethical ideology influences the choice of business behavior in terms of determining assessment criteria in evaluating decisions and recommendations relating to the evaluation (Giacalone et. Al. 1995). Ethical Ideology is measured by 6 items (Henle et.al) which concern:

1. Not intentionally harming others.

2. Not tolerating actions that will pose risks to others.

3. Expressing guilt for actions that harm other people no matter how much personal gain will be obtained.

4. Not taking actions that harm others both physically and psychologically.

5. Not taking actions that will threaten the dignity and wealth of others.

6. Not sacrificing the dignity and wealth of others for the benefit of themselves or groups.

In making decisions including decisions about proposing the budget for its division, a manager is faced with a problematic dilemma of whether to build gaps or to propose according to estimates that will be realized. At this point, an ethical problem will emerge, namely choosing alternatives. If one's ethical ideology is high, in any dilemmatic situation he or she will not make a wrong or bad decision. Conversely, if a person's ethical ideology is low, one will make the most of his or her own interests if there is an opportunity to do so. 


\subsection{Earnings Management}

The relationship between the management and external stakeholders, especially shareholders, can be explained using agency theory:

We define an agency relationship as a contract under which one or more persons (the principal(s)) engage another person (the agent) to perform some service on their behalf which involves delegating some decision-making authority to the agent. If both parties to the relationship are utility maximizers, there is good reason to believe that the agent will not always act in the best interests of the principal. The principal can limit divergences from his interest by establishing appropriate incentives for the agent and by incurring monitoring costs designed to limit the aberrant activities of the agent (Jensen \& Meckling, 1976).

From this theory when it is associated with the relationship between corporate managers and division or function managers, corporate managers are the principal and the division or function managers as agents. If both parties are utility maximizers, then the agent is difficult to expect to work in the best interests of the principal but will try to maximize his own interests through earnings management practices. In connection with this condition, both parties will consider agency costs that can be explained by the theory.

Earnings management is also closely related to the information asymmetry situation which is interpreted as follows:

Condition in which at least some relevantinformation is known to some but not all parties involved. Information asymmetry causesmarkets to become inefficient, since all the market participants do not have access to the information they need for their decision making processes. (www.investorwords.com)

In this relationship between the management and external stakeholders this situation occurs. The management has far more complete and detailed information compared to stakeholders. As a result, the management uses this situation to manage earnings.

Earnings management has been practiced for several years. This practice arises when management uses judgment in financial reporting and arranges transactions to amend financial statements for the purpose of misleading some stakeholders regarding the company's economic performance or to influence contracts based on financial statement numbers (Healy \& Wahlen, 1999). This kind of practice has both good and bad sides. The bad side is that it raises costs because of the misallocation of resources. While the good side relates to the potential for improved communication regarding private information to external stakeholders. 
Belkaoui (2004) agreed that various definitions were offered to explain earnings management as a specific design rather than as a principle in accounting. Earnings management can be seen as a useful intervention in the external financial reporting process with the intention of obtaining several benefits through the selection of accounting methods recognized by GAAP or by applying existing methods in a special way (Belkaoui, 2004).

SFAC No. 1 regarding the objectives of corporate financial reporting explains that the general purpose of financial reporting is to provide useful information for economic and business decision makers. SFAC No. 2 emphasizes the quality characteristics of financial information. Financial information must meet the requirements of relevance (predictive value, feedback value, and timeliness), reliability (verifiability and representational faith-fullness). Both conditions must be met in the preparation of financial statements (Wolk, 2001).

In Indonesia various studies on the topic of earnings management have also been carried out. Hadri Kusuma (2006) examined the Impact of earnings management on the Relevance of Accounting Information. Handayani and Rachmadi (2009) on the Effect of Company Size on Earnings Management. Pradipta (2011) concerning Analysis of the Effects of Corporate Governance Mechanisms on Earnings Management. Kusuma and Nugroho (2013) on Analysis of Earnings Smoothing in Non-Manufacturing Companies.

\subsection{Research Framework and Hypotheses Development}

Based on the theoretical review previously discussed, the framework of thought in this study can be described as follows:

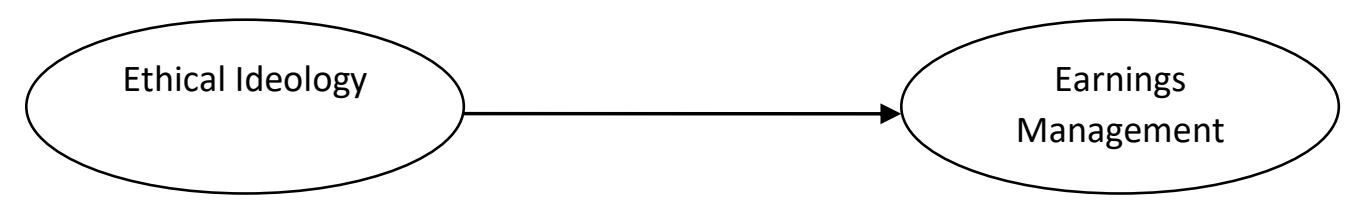

The independent variable in this study is the Ethical Ideology and the Dependent Variable in this study is Earnings Management. Based on the framework of research and theoretical review previously explained, the hypothesis of this study is: Ethical Ideology has negative effect on Earnings Management. 


\subsection{Research Purpose}

Based on the problems that have been stated previously, the purpose of this study is to explore and disclose data and information related to Ethical Ideology and Earnings Management with the aim of knowing the Effect of Ethical Ideology on Earnings Management. With the knowledge of this relationship, it will be useful for a variety of planning and decision-making interests for the management.

\section{METHODOLOGY}

\subsection{Data Source and Selection}

The data in this study were primary data collected using a questionnaire distributed to respondents. The respondents in this study were students of the Accounting Study Program, Faculty of Business and Economics, Universitas Atma Jaya University Yogyakarta, who had passed both Business Ethics and Auditing courses. The number of respondents who fulfilled the statement was 121 people. The data in this study were primary data collected using a questionnaire distributed to respondents.

\subsection{Research Variables' Description}

In this study there is one dependent variable, Earnings Management and one independent variable in the form of Ethical Ideology.

1. Earnings management can be defined as any actions taken by the management that affect net income and which provide real economic benefits to the organization and can even harm the company in the long run (Merchant \& Rockness, 1994: 79).

2. Ethical Ideology is a systematic used to make moral judgments that offer guidelines to assess and resolve behaviors that are most likely to be ethically questioned (Henle et al., 2005).

\subsection{Data Measurement}

\subsubsection{Earnings Management Data Measurement}

The research instrument in the form of a questionnaire to collect ordinal data is a translation of the indicators in the study. The results of the entire questionnaire were then tested to determine its reliability using the SPSS release 16 program. Based on the results of data processing, all the variables were not issued so it can be concluded that the data is valid. From Cronbach's Alphas of 0.830 it can be concluded that the data is reliable. 


\subsubsection{Ethical Ideology Variable Measurement}

The research instrument in the form of a questionnaire to collect ordinal data is a translation of the indicators in the study. The results of the entire questionnaire were then tested to determine its reliability using the SPSS release 16 program. Based on the results of data processing, all the variables were not issued so it can be concluded that the data is valid. From Cronbach's Alpha of 0.618 it can be concluded that the data is reliable.

\section{RESULT AND DISCUSSION}

Using the 2016 Excel Data Analysis linear regression, the following results are obtained:

Table 1. ANOVA Result

ANOVA

\begin{tabular}{|c|c|c|c|c|c|}
\hline & $d f$ & SS & MS & $F$ & $\begin{array}{c}\text { Significance } \\
F\end{array}$ \\
\hline & & & 270,830474 & 7,58880912 & 0,00679653 \\
\hline \multirow[t]{2}{*}{ Regression } & 1 & 270,8304744 & 4 & 5 & 7 \\
\hline & \multicolumn{5}{|c|}{35,6881389} \\
\hline Residual & 119 & 4246,888534 & 4 & & \\
\hline \multirow[t]{4}{*}{ Total } & 120 & 4517,719008 & & & \\
\hline & \multicolumn{3}{|c|}{ Standard } & & \\
\hline & Coefficients & Error & $t$ Stat & $P$-value & Lower 95\% \\
\hline & & & 10,1198281 & & 40,4083136 \\
\hline \multirow[t]{3}{*}{ Intercept } & 50,23818689 & 4,964332038 & 1 & $9,60075 \mathrm{E}-18$ & 4 \\
\hline & & & - & & - \\
\hline & & & 2,75477932 & 0,00679653 & 0,67008686 \\
\hline$x$ & $-0,389860302$ & 0,141521427 & 4 & 7 & 3 \\
\hline
\end{tabular}

From the results of the data processing it can be obtained the regression equation $Y=50.238-0.39 \mathrm{X}$. Based on the regression equation it can be interpreted that the magnitude of the Earnings Management variable is negatively and significantly affected by the Ethical Ideology variable. The greater the Ethical Ideology, the intention to practice earnings management will decrease.

From these results it can also be concluded that if the Ethical Ideology is raised by one unit, the Earnings Management will decrease by 0.39 units. Therefore, to reduce the intention of earnings management practices, company's management 
must conduct various training in the field of Ethics so that it is expected to be able to improve Ethical Ideology.

Based on these results, the research hypothesis that ethical ideology has a negative effect on earnings management is not rejected. Thus, the hypothesis is tested.

\section{CONCLUSION}

\subsection{Conclusion}

Based on the results of the analysis that has been done before, it can be concluded that the ethical ideology variable has a significant negative effect on earnings management, thus it can be interpreted if the ethical ideology variable is raised, the earnings management will decrease. Or in other words the research hypothesis was not rejected.

\subsection{Suggestion}

Based on the results of the analysis and conclusions that have been presented, the following points can be suggested that all levels of the company's management make efforts to improve ethical ideology so that the intention to manage earnings can be lowered. According to realize the suggestions in point 1 , various types of training in the area of business ethics can be carried out.

\section{REFERENCES}

Ashman, I. \& Diana, W., 2006. The Ethics of organizational commitment Business Ethics: A European Review, 15(2) pp.142-153.

Belkaoui, A. 2004. Accounting Theory (5th ed.) Singapore: Thompson Learning.

Brunc, W.J. \& Merchant, K.A. 1990. The dangerous morality of managing earnings. Management Accounting, 72(2), pp. 22-25.

Clikeman, P., Greiger, M. \& O'Connell, B. 2001. Student perceptions of earnings management: the effects of national origin and gender. Teaching Business Ethics, 5(4), pp. 389-410.

De Connick J.B \& Lewis W.F. 1997. The Influence of Deontological and Teleological Consideration and Ethical Climate on Sales Manager's Intention to reward or Punish Salesforce Behavior. Journal of Business Ethics,16 (5), pp. 497-506.

De George, R.T. 1993. Competing with Integrity in International Business. New York. Oxford University Press. 
Richard T. 1995. Business Ethics $4^{\text {th }}$ Edition. New Jersey. Prentice Hall Inc.

Elias, R. 2004. The impact of corporate ethical values on perceptions of earnings management. Managerial Accounting Journal, 19(1), pp. 84-98.

Fischer, M. \& Rosenzweig, K. 1995. Attitudes of students and accounting practitioners concerning the ethical acceptability of earnings management. Journal of Business Ethics, 14(6), pp. 433-444.

Forsyth D.R. 1992. Judging the Morality of Business Practices: The Influence of Personal Moral Philosophies. Journal of Business Ethics, 11(5), pp. 461-470.

Giacalone R.A, Fricker S. \& J.W. Beard. 1995. The Impact of Ethical Ideology on Modifiers of Ethical Decisions and Suggested Punishment for Ethical Interaction. Journal of Business Ethics, 14(7), pp. 497 - 510.

Giacomino, D.E. \& Akers, M. 2006. The ethics of managing short-term earnings: business managers and business students have few problems with earnings management practices. Journal of College Teaching \& Learning, July, pp. 57-71.

Handayani, Sri R.R \& Rachmadi A.D. 2009. Pengaruh Ukuran Perusahaan terhadap manajemen Laba. Jurnal Bisnis dan Akuntansi, 11(1).

Healy, P.M. \& Wahlen, J.M. 1999. A review of the earnings management literature and its implications for standard setting. Accounting Horizons, 13(4), pp. 365-383.

Henle, C. R. Giacalone \& C. Jurkiewicz. 2005. The Role of Ethical Ideology in Workplace Deviance. Journal of Business Ethics, 56, pp. 219-230.

Jensen, M.C. \& William H.M. 1976. Theory of the Firm: Managerial Behavior, Agency Costs and Ownership Structure. Journal of Financial Economics, October, 3(4), pp. 305-360.

Kaplan, S.E. 2001. Ethically related judgments by observers of earnings management. Journal of Business Ethics, 32, pp. 285-298.

Kohlberg, L.1984. The Psychology of Moral Development. San Fransisco: Harper \& Row Publisher.

Kusuma, H. 2006. Dampak Manajemen Laba terhadap Relevansi Informasi Akuntansi: Bukti Empiris dari Indonesia. Jurnal Akuntansi dan Keuangan, 8(1), pp.1-12. Retrieved from http://203.189.120.190/ejournal/index.php/aku/article/download/16578/16570, June 26, 2016. 
Kusuma, L.S.A. \& Paskah Ika Nugroho 2013. Analisis Perataan Laba pada Perusahaan Manufaktur. Jurnal Manajemen, 12(2), May.

Pradipta, Arya. 2011. Analisis Pengaruh Mekanisme Corporate Governance terhadap Manajemen Laba. Jurnal Bisnis dan Akuntansi, 13(2), Agustus, pp. 93106.

Velasquez, M.G. 2014. Business Ethics: Concepts and Cases. New Jersey: Pearson Prentice-Hall.

Widodo, Sri, 2015. Pengaruh Komitmen Organisasional terhadap Senjangan Anggaran dengan Ideologi Etis sebagai variabel Pemoderasi. Kinerja, 19(2), September.

Wolk, H. I., Michael G.T. \& James L.D. 2001. Accounting Theory: A Conceptual and Institutional Approach $5^{\text {th }}$ Edition. Cincinnati, Ohio: South Western College Publishing. 